\title{
UPAYA PENCEGAHAN STUNTING SEJAK PRA KONSEPSI MELALUI MODUL NKR_CATEN DAN KONSELING
}

\author{
Triawanti $^{1}$, Didik Dwi Sanyoto ${ }^{2}$, Fujiati' ${ }^{1}$, Bambang Setiawan', Emmi Erliyanti ${ }^{1}$, Siti Juliati ${ }^{1}$ \\ ${ }^{1}$ Departemen Biokimia Biomolekuler Fakultas Kedokteran Universitas Lambung Mangkurat Banjarmasin \\ ${ }^{2}$ Departemen Biomedik Fakultas Kedokteran Universitas Lambung Mangkurat Banjarmasin
}

triawanti@ulm.ac.id,didikdwisanyoto@ulm.ac.id, fujiati_fkunlam@yahoo.co.id, ganesh79setiawan@gmail.com, emmierliyanti@gmail.com, sitijuliati@gmail.com

\begin{abstract}
Abstrak
Prevalensi balita stunting di Kalimantan Selatan tahun 2018 sebesar 31\%, balita kurus dan sangat kurus sebesar 10,2\%. Di Kabupaten Banjar jumlah kecamatan yang bebas rawan gizi hanya 31,5\%. Faktor yang berpengaruh meliputi kondisi fisik, umur dan pengetahuan ibu. Status gizi dan asupan nutrisi yang baik pada pra-kehamilan ikut menentukan dan dapat diantisipasi sejak dini. Calon penganten (Caten ) merupakan sasaran yang tepat dalam pencegahan permasalahan gizi. Tujuan kegiatan ini adalah untuk meningkatkan pengetahuan pasangan caten tentang kesehatan reproduksi, nutrisi, dan tumbuh kembang bayi. Metode kegiatan: 1) pembuatan modul NKR_CATEN; 2) pencetakan modul; 3) membagikan modul sekaligus pemberian konseling kepada calon penganten; dan 4) Evaluasi kegiatan. Mitra kegiatan yaitu Kantor Urusan Agama (KUA) Kecamatan Martapura Barat. Hasil kegiatan didapatkan usia calon penganten yang terlibat kegiatan ini rata-rata di atas 20 tahun dan pendidikan setingkat SMA dan PT sebanyak 50\%. Hal ini menjadi modal yang baik bagi caten untuk memberikan pengasuhan bagi anak-anaknya. Setelah pemberian modul NKR_CATEN dan konseling pada calon penganten terlihat peningkatan pengetahuan calon penganten pada saat posttest. Nilai rerata yang diperoleh lebih tinggi dibanding pretest. Kesimpulan: pemberian modul NKR-CATEN dapat meningkatkan pengetahuan calon penganten mengenai nutrisi dan kesehatan reproduksi. Diharapkan modul NKR-CATEN dapat diterapkan di tempat lain.
\end{abstract}

Kata Kunci : stunting, modul NKR_CATEN, calon penganten

\section{PENDAHULUAN}

Malnutrisi merupakan masalah yang masih dihadapi Indonesia sampai saat ini. Bentuk-bentuk malnutrisi antara lain, gizi kurang, gizi buruk, kurus, sangat kurus dan stunting yaitu pendek dan sangat pendek. Stunting merupakan suatu kegagalan untuk mencapai pertumbuhan yang optimal diukur berdasarkan tinggi badan per umur (TB/U) dikategorikan menjadi pendek dan sangat pendek. Laporan Riskesdas 2018 prevalensi pendek dan sangat pendek pada balita di Indonesia sebesar 30,8\%. Di Kalimantan Selatan prevalensi balita pendek dan sangat pendek tahun 2018 sebesar $31 \%$ (Kementerian Kesehatan 2018). Berdasarkan Data dan Informasi Profil Kesehatan Indonesia tahun 2017 prosentase balita kurus dan sangat kurus di Kalimantan Selatan sebesar 10,2\% diatas rata-rata nasional yang hanya 9,5\% (Kemenkes RI, 2017). Di Kabupaten Banjar pada tahun 2016 prevalensi gizi kurang dan BGM pada balita sebesar 4,8\%, dan jumlah kecamatan yang bebas rawan gizi hanya berjumlah 31,5\% (Dinas Kesehatan Kab. Banjar, 2017). Kecamatan Martapura Barat termasuk kecamatan yang belum bebas rawan gizi, artinya

$$
\text { Pangan dan Kesehatan }
$$


angka prevalensi gizi kurang dan buruk lebih dari $15 \%$ termasuk di dalamnya masalah stuntng.

Stunting merupakan kekurangan gizi kronis atau kegagalan pertumbuhan dimasa lalu dan digunakan sebagai indikator jangka panjang untuk gizi kurang pada anak. Anak yang memiliki status gizi kurang atau buruk dan pendek atau sangat pendek mempunyai risiko kehilangan kecerdasan atau intelligence quotient (IQ) sebesar $10-15$ poin (Kementrian Bappenas, 2011). Menurut laporan UNICEF (1998) anak-anak yang mengalami stunted lebih awal yaitu sebelum usia enam bulan, akan mempengaruhi kesehatan dan perkembangan anak serta mengganggu pertumbuhan dan perkembangan kognitif. Anak stunted pada usia lima tahun cenderung menetap sepanjang hidup, kegagalan pertumbuhan anak usia dini berlanjut pada masa remaja dan kemudian tumbuh menjadi wanita dewasa yang stunted dan mempengaruhi secara langsung pada kesehatan, sehingga meningkatkan peluang melahirkan anak dengan BBLR. Stunted terutama berbahaya pada perempuan, karena lebih cenderung menghambat dalam proses pertumbuhan dan berisiko lebih besar meninggal saat melahirkan (UNICEF, 1998).

Banyak faktor yang menyebabkan malnutrisi di masa anak-anak antara lain retardasi pertumbuhan intra-uterus, berat badan lahir rendah BBLR), ASI eksklusif yang tidak memadai, makanan pendamping ASI yang tidak tepat, pendidikan dan pengetahuan gizi ibu yang rendah, asupan mikronutrien dan energi yang tidak cukup, jarak lahir yang terlalu rapat dan paritas yang tinggi, latar belakang sosial ekonomi termasuk ketersediaan pangan dan perumahan, sanitasi dan pelayanan kesehatan yang buruk dan infeksi penyakit (Khan et al., 2016)

Asupan nutrisi yang baik pada prakehamilan, masa kehamilan, masa menyusui dan pemberian makanan pendamping merupakan faktor utama yang menentukan dan hal ini dapat diantisipasi sejak dini (Triawanti dkk, 2018 ${ }^{\mathrm{b}}$ ). Calon penganten (calon penganten) merupakan sasaran yang baik dalam pencegahan stunting maupun permasalah gizi terhadap tumbuh kembang pada bayi yang akan dilahirkannya kelak. Calon penganten baik perempuan maupun laki-laki harus memiliki status kesehatan yang optimal untuk menghasilkan keturunan yang terbaik. Status kesehatan yang optimal dapat dicapai apabila kedua calon pengantin memiliki pengetahuan yang baik terkait hal tersebut. Untuk itu perlu dilakukan peningkatan pengetahuan calon pengantin tentang kesehatan reproduksi, nutrisi, dan tumbuh kembang bayi sejak sebelum konsepsi terjadi. Upaya tersebut dapat dilakukan dengan memberikan modul panduan kesehatan reproduksi dan nutrisi keluarga bagi calon penganten disertai dengan konsultasi langsung pada saat calon penganten mendapatkan nasehat perkawinan di Kantor Urusan Agama (KAU) setempat.

Kecamatan Martapura Barat memiliki penduduk berjumlah 18.534 jiwa dengan rasio lakilaki dan perempuan yaitu 106,12, dan usia penduduk terbanyak adalah 15-64 tahun $(72,66 \%)$. Pekerjaan penduduknya paling banyak adalah petani $(45,25 \%)$ (Disdukcapil Kab. Banjar \& Kec. Martapura Barat, 2017). Kecamatan Martapura Barat merupakan salah satu kecamatan di Kabupaten Banjar yang belum bebas rawan gizi (Dinkes Kabupaten Banjar, 2017). Banyak faktor yang mempengaruhi gizi kurang dan gizi buruk pada bayi yang dilahirkan antara lain kondisi fisik ibu, umur ibu dan pengetahuan ibu. Seorang ibu dengan kekurangan energi kronis (KEK) dan anemia rentan melahirkan bayi berat lahir rendah (BBLR) dan kecil menurut usia kehamilan (KMK) (Chyntia dkk, 2017), sehingga perlu dilakukan peningkatan status gizi ibu maupun calon ibu sebelum terjadi konsepsi. Demikian juga dengan umur ibu yang < 20 tahun memiliki risiko untuk melahirkan bayi prematur, BBLR dan KMK. Di Kabupaten Banjar angka pernikahan dini usia 14 tahun selama tahun 2017 sebanyak 1.816 kasus, usia 15 tahun sebanyak 3.734 kasus, usia 16 tahun sebanyak 5323 kasus, pernikahan usia 17 tahun tercatat 11.561 kasus, 18 tahun terdata 12.326 tahun, 19 tahun tercover 11.458 kasus dan pernikahan usia 20 tahun untuk istri pertama sebanyak 22.514 kasus (jejak rekam). Hal ini menimbulkan kerawanan terjadinya kehamilan di usia muda ( $<20$ tahun) sehingga akan menimbulkan banyak masalah. Bukan hanya pada kesehatan dan keselamatan ibu tetapi juga pada kesehatan dan keselamatan janin yang dikandungnya. 
Faktor lain yang juga berhubungan dengan status gizi bayi yang dilahirkan yaitu pendidikan dan pengetahuan ibu. Rata-rata tingkat pendidikan kepala keluarga di Kecamatan Martapura Barat yaitu tamat $\mathrm{SD} /$ sederajat $(62,04 \%)$. Untuk kepala keluarga yang dipegang oleh perempuan tingkat pendidikan tertinggi yaitu tidak sekolah $48,96 \%$, tidak tamat SD 35,10\%, dan tamat SD 17,55\% (Disdukcapil Kab. Banjar \& Kec. Martapura Barat, 2017). Tingkat pendidikan ini dapat mempengaruhi pengetahuan ibu tentang suatu masalah atau konsep. Orang yang dengan tingkat pendidikan rendah maka biasanya pengetahuannya juga kurang. Akan tetapi pengetahuan dapat ditingkatkan melalui pendidikan nonformal, pengalaman maupun perolehan informasi dari pihak lain.

Permasalahan gizi yang dihadapi oleh masyarakat Kecamatan Martapura Barat yaitu belum tercapainya kecamatan bebas rawan gizi dapat dipecahkan melalui peningkatan pengetahuan calon penganten terhadap kesehatan reproduksi, nutrisi, dan tumbuh kembang bayi sejak sebelum konsepsi terjadi.

\section{METODE}

\section{Mitra Kegiatan}

Pada kegiatan pengabdian ini yang menjadi mitra yaitu Kantor Urusan Agama Kecamatan Martapura Barat dengan sasaran kegiatan yaitu pasangan calon pengantin yang mengurus suratsurat pernikahan.

\section{Prosedur pelaksanaan}

Pelaksanaan kegiatan meliputi 1) persiapan pembuatan modul dan perizinan kegiatan ke KUA; 2) pembuatan modul NKR_CATEN; 3) kunjungan ke KUA sekaligus penyuluhan dan konseling. Persiapan pembuatan modul kesehatan reproduksi dan nutrisi bagi calon penganten dimulai dengan mengumpulkan materi-materi yang sesuai dengan tujuan pembuatan modul. Materi modul meliputi: 1) Organ reproduksi wanita; 2) Organ reproduksi pria; 3) Masalah kesehatan yang sering muncul pada organ reproduksi; 4) Kebutuhan zat gizi bagi wanita usia subur, hamil dan menyusui; 5) Kebutuhan zat gizi bagi janin dan bayi; 6) Kehamilan dan permasalahannya.

Pembuatan materi modul dilakukan dengan mengambil referensi-referensi terkini dan dibuat dalam bahasa sederhana yang mudah dipahami oleh orang awam. Pencetakan modul dilakukan setelah seluruh materi telah tersusun dengan baik.

Langkah selanjutnya membuat kesepakatan dan jadwal bersama Kepala KUA atau yang mewakili untuk pembagian modul sekaligus melakukan penyuluhan dan konseling. Kegiatan penyuluhan dan konseling dihadiri oleh seluruh calon penganten bersamaan waktunya dengan pemberian nasehat perkawinan.

Pembagian modul dan pemberian penyuluhan dan konseling kepada calon penganten dilakukan setelah calon penganten mendapat nasehat perkawinan dari petugas KUA. Sebelum modul dibagikan dan pemberian penyuluhan/konseling, dilakukan pretest bagi seluruh peserta. Pretes dilakukan dengan cara memberi lembar pertanyaan yang berisi 10 pertanyaan dengan pilihan jawaban Benar atau Salah. Kemudian dilanjutkan penyuluhan yaitu dengan menjelaskan materi yang ada dalam modul NKR_CATEN secara interaktif dua arah. Setelah proses penyuluhan dan konseling dilanjutkan tanya jawab dan konseling untuk pasangan yang menanyakan pertanyaan ataupun masalah. Setelah penyuluhan dan tanya jawab selesai, peserta diminta untuk mengisi lembar postes. Pertanyaan untuk pretes dan postes dibuat sama sehingga dapat mengukur apakah terjadi peningkatan pengetahuan peserta setelah diberi penyuluhan. Soal pretes dan postes meliputi materi yang ada di modul CATEN_NKR yaitu tentang kesehatan reproduksi serta gizi untuk calon ibu dan ayah. Di akhir kegiatan dilakukan evaluasi pelaksanaan kegiatan dilakukan bersama-sama dengan Kepala KUA atau yang mewakili. Data tentang karakteristik peserta dan hasil pretes/postes yang diperoleh ditabulasi dan dianalisis secara deskriptif.

\section{HASIL DAN PEMBAHASAN}

Asupan gizi yang baik pada calon ibu sangat dibutuhkan untuk persiapan kehamilan yang optimal. Asupan gizi dapat dipengaruhi oleh tingkat pendapatan keluarga. Asupan gizi yang baik bagi calon ibu dan ibu hamil dapat ditingkatkan tanpa perlu membeli bahan makanan yang mahal, tetapi dapat memanfaatkan sumber daya alam lokal yang tersedia. Pengolahan makanan yang baik juga diperlukan untuk mendapatkan zat-zat gizi yang

$$
\text { Pangan dan Kesehatan }
$$


sesuai dengan kebutuhan. Hal ini dapat tercapai apabila calon ibu memiliki pengetahuan tentang konsep nutrisi yang baik.

Pada kegiatan ini telah dibuat modul NKR_CATEN yang berisi materi tentang kesehatan reproduksi dan nutrisi bagi calon penganten. Materi ditulis dalam bahasa yang mudah dipahami dan gambar-gambar untuk menarik minat membaca. Penjabaran materi dibuat dalam bentuk tanya jawab sehingga pembaca lebih mudah memahaminya (Gambar 1). Contoh materi pertanyaan dan jawaban dalam modul NKR_CATEN antara lain : 1) Apa itu Nutrisi? Nutrisi adalah Nutrisi adalah zat-zat gizi yang diperlukan oleh tubuh kita agar tetap sehat dan berfungsi optimal. Zat-zat gizi ini berupa karbohidrat, lemak, protein, vitamin, mineral dan air yang terdapat di dalam bahan makanan yang kita makan. Di masyarakat biasa digaungkan sebagai makanan seimbang. 2) Apa yang dimaksud kesehatan reproduksi? Adalah keadaan yang menunjukkan kondisi kesehatan tubuh yang mempengaruhi proses reproduksi, dan seterusnya (Gambar 1). Pada modul ini terdapat 16 materi tanya jawab seputar kesehatan reproduksi dan nutrisi.

Calon penganten yang terlibat dalam kegiatan ini berjumlah 14 orang memiliki usia ratarata di atas 20 tahun dan pendidikan setingkat SMA dan PT sebanyak 50\%. Usia calon penganten perempuan hanya 1 yang di bawah usia 20 tahun, sedangkan calon penganten laki-laki seluruhnya di atas 20 tahun. Hal ini telah sesuai dengan usia paling baik bagi seorang perempuan untuk menikah. Pada usia di atas 20 tahun seluruh organ reproduksi perempuan telah terbentuk dengan sempurna sehingga mengurangi risiko terjadinya kelainan dan komplikasi pada kehamilan. Dengan demikian diharapkan pada saat hamil ibu sehat, aman saat melahirkan, dan anak yang dilahirkan sehat.

Salah satu faktor penyebab langsung yang paling menentukan status gizi bayi dan balita adalah asupan gizi yang tidak memenuhi jumlah dan komposisi zat gizi yang dipersyaratkan terutama pada 1000 hari pertama kehidupan. Periode yang krusial pada perkembangan metabolik dan kognitif bayi terjadi selama 1000 hari pertama kehidupan yang dapat dibagi menjadi 3 fase yaitu kehamilan ( 9 bulan), ASI eksklusif (6 bulan) dan pemberian makanan pendamping (18 bulan). Stunting dapat berawal dari kesehatan ibu saat hamil yang berisiko mengalami intra uterine growth retardation (IUGR). Intra uterine growth retardation dapat terjadi pada ibu dengan TB/U yang pendek, IMT yang rendah dan peningkatan BB saat hamil yang kurang. Faktor gizi yang juga berperan pada kasus stunting adalah asupan zat besi, asam folat, vitamin B kompleks, Copper, selenium, zinc, kalsium dan magnesium. Faktor-faktor tersebut disebut faktor pre natal (Prentice et al., 2012 dalam Triawanti dkk, $\left.2018^{\mathrm{a}}\right)$.

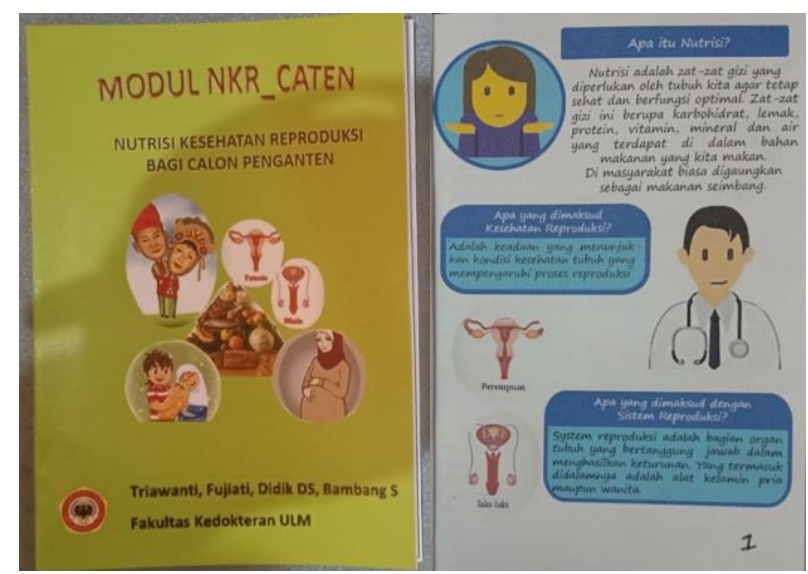

Gambar 1. Tampilan cover dan isi modul NKRCATEN

Retni dkk (2016) menemukan bahwa pada ibu hamil remaja, asupan energi, protein, asam folat dan zat besi yang rendah merupakan faktor risiko melahirkan bayi BBLR. Asupan energi yang rendah pada ibu hamil remaja mempunyai risiko 6,03 kali lebih besar untuk melahirkan bayi BBLR dibandingkan ibu hamil dengan asupan energi cukup. Asupan protein yang rendah pada ibu hamil mempunyai risiko 13 kali lebih besar untuk melahirkan bayi BBLR dibandingkan ibu hamil dengan asupan protein cukup. Asupan asam folat yang rendah pada ibu hamil remaja mempunyai risiko 13 kali lebih besar untuk melahirkan bayi BBLR dibandingkan ibu hamil dengan asupan asam folat cukup. Asupan zat besi yang rendah pada ibu hamil remaja mempunyai risiko 4 kali lebih besar untuk melahirkan bayi BBLR dibandingkan ibu hamil dengan asupan zat besi cukup.

$$
\text { Pangan dan Kesehatan }
$$




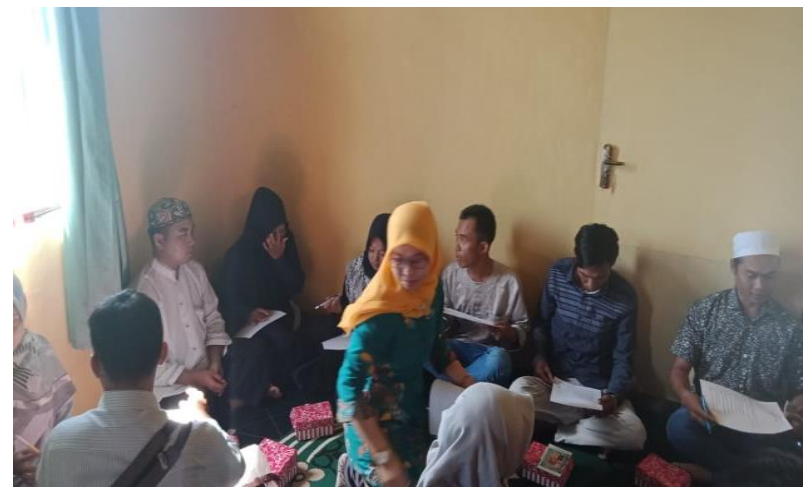

Gambar 2. Calon penganten mengerjakan pretes

Pendidikan merupakan salah satu faktor yang mempengaruhi status gizi. 50\% pendidikan calon penganten tergolong dalam pendidikan menengah. Hal ini menjadi modal yang baik bagi calon penganten untuk dapat memberikan pengasuhan bagi anak-anaknya. Untuk yang berpendidikan tingkat dasar (SD dan SMP/sederajat) dapat meningkatkan pengetahuannya dengan banyak membaca dan mendengarkan penyuluhan dari petugas puskesmas.

Nilai pretes calon penganten rerata 7,42 dan setelah diberikan modul NKR serta konseling diperoleh nilai postes yang meningkat yaitu 9,28 (Tabel 1). Pada saat diberikan pretes, kebanyakan calon penganten salah dalam menjawab pertanyaan tentang anak keturunan yang sehat hanya dipengaruhi oleh kesehatan calon ibu mencapai $85 \%$ (Tabel 2). Hal ini menunjukkan bahwa banyak calon penganten yang memiliki persepsi bahwa kesehatan anak hanya ditentukan oleh kesehatan calon ibu. Akan tetapi setelah diberikan modul dan konseling maka yang menjawab salah menurun menjadi $42 \%$. Kesehatan seorang bayi yang dilahirkan ditentukan sejak awal pembuahan bahkan dapat dipersiapkan jauh sebelum terjadi pembuahan yaitu sejak seorang perempuan dan laki-laki mempersiapkan pernikahan. Perempuan dan lakilaki yang akan menikah harus memiliki kesehatan yang baik dan kebiasan hidup yang sehat agar sel telur dan sel sperma yang dihasilkan berkualitas baik. Untuk itu perlu diberikan pengetahuan kepada calon penganten agar benar-benar memperhatikan kesehatan masing-masing.
Tabel 1. Nilai pretes dan postes calon penganten

\begin{tabular}{|c|c|c|c|}
\hline $\begin{array}{c}\text { Pasangan } \\
\text { Caten }\end{array}$ & Pretes & Postes & Perubahan \\
\hline 1 & 10 & 10 & 0 \\
\hline 2 & 8 & 10 & 2 \\
\hline 3 & 6 & 10 & 4 \\
\hline 4 & 6 & 9 & 3 \\
\hline 5 & 8 & 8 & 0 \\
\hline 6 & 6 & 10 & 4 \\
\hline 7 & 8 & 8 & 0 \\
\hline $\begin{array}{c}\text { Rerata } \\
\text { nilai }\end{array}$ & 7,42 & 9,28 & 1,86 \\
\hline
\end{tabular}

Penelitian Rahardjo dan Kusumawati menemukan hubungan antara pengetahuan dengan perilaku KADARZI di Purwokerto Selatan. Di daerah perkotaan sebagian besar responden (56.3\%) menempuh pendidikan sampai tingkat lanjut yaitu tamat SMA dan tamat perguruan tinggi. Semakin tinggi tingkat pendidikan seseorang akan semakin luas pengetahuannnya. Semakin tinggi pengetahuan dan pemahaman terhadap kesehatan, akan meningkatkan pula cara pandang terhadap konsep sehat dan sakit menjadi mantap yang pada akhirnya akan mempengaruhi pandangan, cara hidup dan upaya seseorang untuk dapat meningkatkan derajat kesehatan. Pengetahuan keluarga khususnya suami tentang Kadarzi yang tinggi akan menjadi motivator terjadinya perilaku Kadarzi didalam keluarga, didukung oleh pendidikan istri dan aktivitas istri.

Upaya pemberian modul NKR_CATEN dan konseling yang dilakukan saat ini merupakan salah satu upaya untuk meningkatkan kesehatan reproduksi dan nutrisi bagi calon penganten. KUA merupakan salah satu mitra yang baik dalam program penanggulangan masalah gizi di masyarakat. Setiap calon penganten pasti berurusan dengan KUA untuk mendaftarkan pernikahannya, sehingga momen ini dapat dimanfaatkan oleh petugas kesehatan untuk memberikan penyuluhan dan konseling kepada calon penganten. Selain KUA, program pemberian modul ini juga dapat bermitra dengan Kantor Catatan Sipil dan Puskesmas. 
Tabel 2. Prosentase jawaban benar dan salah berdasarkan butir pertanyaan

\begin{tabular}{|c|c|c|c|}
\hline \multirow[t]{2}{*}{ No. } & \multirow[t]{2}{*}{ Pernyataan } & \multicolumn{2}{|c|}{$\begin{array}{l}\text { Jumlah } \\
\text { jawaban }\end{array}$} \\
\hline & & Benar & Salah \\
\hline 1. & $\begin{array}{l}\text { Calon pengantin } \\
\text { perempuan dan laki-laki } \\
\text { harus memiliki organ } \\
\text { reproduksi yang sehat }\end{array}$ & 7 & 0 \\
\hline 2. & $\begin{array}{l}\text { Calon pengantin tidak } \\
\text { boleh mengonsumsi ikan } \\
\text { dan daging }\end{array}$ & 6 & 1 \\
\hline 3. & $\begin{array}{l}\text { Makanan yang baik bagi } \\
\text { calon ibu harus } \\
\text { mengandung antara lain } \\
\text { protein, asam lemak } \\
\text { omega 3, zat besi dan } \\
\text { asam folat }\end{array}$ & 7 & 0 \\
\hline 4. & $\begin{array}{ll}\text { Makanan yang } & \text { banyak } \\
\text { mengandung } & \text { kalsium } \\
\text { tidak baik untuk calon ibu }\end{array}$ & 4 & 3 \\
\hline 5. & $\begin{array}{l}\text { Seorang calon ibu harus } \\
\text { memiliki ukuran lingkar } \\
\text { lengan atas lebih dari } 23,5 \\
\mathrm{~cm}\end{array}$ & 5 & 2 \\
\hline 6. & $\begin{array}{l}\text { Calon ibu yang kurang } \\
\text { gizi dapat melahirkan } \\
\text { anak dengan berat lahir } \\
\text { rendah (bayinya kecil) }\end{array}$ & 5 & 2 \\
\hline 7. & $\begin{array}{l}\text { Kebiasaan merokok } \\
\text { seorang ayah dapat } \\
\text { mempengaruhi kesehatan } \\
\text { istri dan anaknya }\end{array}$ & 6 & 1 \\
\hline 8. & $\begin{array}{l}\text { Ibu hamil memiliki } \\
\text { pantangan makan ikan }\end{array}$ & 6 & 1 \\
\hline 9. & $\begin{array}{l}\text { Seorang istri sebaiknya } \\
\text { tidak hamil dulu jika usia } \\
\text { masih di bawah } 20 \text { tahun }\end{array}$ & 5 & 2 \\
\hline 10. & $\begin{array}{l}\text { Anak keturunan sehat dan } \\
\text { cerdas hanya ditentukan } \\
\text { oleh kesehatan calon ibu } \\
\text { (istri) }\end{array}$ & 1 & 6 \\
\hline
\end{tabular}

Hasil dari pemberian modul NKR_CATEN dan konseling pada calon penganten dapat terlihat pada peningkaan pengetahuan calon penganten pada saat postest. Nilai rerata yang diperoleh menjadi lebih tinggi dibanding pretest. Untuk pemahaman tentang kesehatan keturunan ditentukan oleh kedua orang tua juga menjadi lebih baik. Artinya calon penganten menjadi lebih paham tentang asupan nutrisi dan kesehatan reproduksi yang baik pada calon ayah dan ibu sangat mempengaruhi kesehatan dan kecerdasan keturunannya.

Nutrisi untuk ibu hamil sangat bermanfaat untuk mendukung proses kehamilan, proses metabolisme zat gizi dan mendukung kondisi fetus dan neonatus. Peningkatan kebutuhan energi dan zat gizi tersebut diperlukan untuk tumbuh kembang janin, pertambahan besarnya organ kandungan serta perubahan komposisi dan metabolisme ibu, sehingga kekurangan zat gizi tertentu saat kehamilan dapat menyebabkan gangguan pada pertumbuhan janin (Proverawati dan Wati, 2017).

Hasil kegiatan ini diharapkan dapat diterapkan di KUA-KUA kecamatan lain, Puskesmas-puskesmas dan Kantor Catatan Sipil yang melayani administrasi calon penganten agama lain. Dengan berjalannya program ini maka permasalahan stunting pada bayi dan balita serta anemia gizi pada wanita usia reproduksi (WUS) maupun ibu hamil dapat dicegah dan ditanggulangi dengan baik.

\section{KESIMPULAN}

Berdasarkan hasil kegiatan pengabdian yang dilakukan maka dapat disimpulkan bahwa pemberian modul NKR_CATEN dan konseling dapat meningkatkan pengetahuan calon penganten tentang pentingnya nutrisi dan kesehatan reproduksi calon ayah dan calon ibu bagi kesehatan anak keturunannya. Diharapkan Modul NKR_CATEN ini dapat digunakan di tempat lain misalnya puskesmas dan kantor catatan sipil dimana calon penganten dari agama lain mencatatkan pernikahannya.

\section{UCAPAN TERIMAKASIH}

Ucapan terimakasih disampaikan kepada Fakultas Kedokteran Universitas Lambung Mangkurat yang telah memberikan dana hibah pengabdian kepada masyarakat tahun anggaran 2019 dan Kantor Urusan Agama Kecamatan Martapura Barat Kabupaten Banjar yang telah bersedia menjadi mitra kegiatan. 


\section{REFERENSI}

Badan Perencanaan Pembangunan, Penelitian, dan Pengembangan Kabupaten Banjar (2017). Statistik Pembangunan Kabupaten Banjar 2017.

Cynthia PH, Siti FP, M Zein R (2017). Faktor-faktor yang Berhubungan Dengan Kejadian Berat Badan Lahir Rendah (BBLR) di Kabupaten Kudus. (Studi di wilayah kerja Puskesmas Undaan Kecamatan Undaan Kabupaten Kudus tahun 2015). Jurnal kesehatan Masyarakat (e-journal) 5(1): 322331.

Dinkes Kabupaten Banjar (2017). Profil Kesehatan Kabupaten Banjar.

Disdukcapil Kab. Banjar \& Kec. Martapura Barat (2017). Profil Perkembangan Kependudukan Kecamatan Martapura Barat.

Kemenkes RI (2017). Data dan Informasi Profil Kesehatan Indonesia 2017.

Kementerian Bappenas (2011). Rencana aksi nasional pangan dan gizi 2011-2015. Kementerian Perencanaan Pembangunan Nasional/ Badan Perencanaan Pembangunan Nasional (BAPPENAS). Jakarta: Indonesia

Kemenkes RI (2018). Hasil Utama Riset Kesehatan Dasar 2018. Jakarta: Indonesia

Khan GN, Turab A, Khan MI, Rizvi A, Shaheen F, Ullah A, Hussain A, Hussain I, Ahmed I, Yaqoob M, Ariff S and Soofi SB (2016). Prevalence and Associated Factors of Malnutrition Among Children Under-five Years in Sindh, Pakistan: a cross-sectional study. BMC Nutrition 2:69.
Proverawati A dan Wati EK (2017). Ilmu Gizi Untuk Keperawatan \& Gizi Kesehatan, Nuha medika, Yogyakarta

Rahardjo S dan Kusumawati E (2011). Hubungan Tingkat Pendidikan dan Pengetahuan dengan Perilaku Keluarga Sadar Gizi (Kadarzi) Pada Masyarakat Perkotaan dan Perdesaan di Kabupaten Banyumas. Kesmasindo 4 (2):150-158.

Retni, Margawati A dan Widjanarko B (2016). Pengaruh Status Gizi dan Asupan Gizi Ibu Terhadap Berat Bayi Lahir Rendah Pada Kehamilan Usia Remaja. Jurnal Gizi Indonesia, 5 (1): 14-19.

Triawanti, Yunanto A, Sanyoto DD, Nur'amin HW. (2018 $\left.{ }^{\mathrm{a}}\right)$. Nutritional Status Improvement Rat (Rattus norvegicus) After Selung Fish (Rasbora spp.) Treatment. Current Research in Nutrition and Food Science, 06(1): 127-134.

Triawanti, Yunanto A, Sanyoto DD (2018 $)$. Kapita Selekta Malnutrisi. Penerbit Sari Mulia Indah. Banjarmasin

WHO (2013). Childhood Stunting: Context, Causes and Consequences dalam http://www.who.int/nutrition/, di akses 12 November 2016. 